\title{
SIMILARITIES AND DIFFERENCES IN ATTITUDES OF GREEK EDUCATORS TOWARDS STUDENTS WITH SPECIAL EDUCATIONAL NEEDS AND MIGRANT STUDENTS: SOCIAL-DEMOGRAPHIC DIFFERENCES
}

\author{
Stavroula-Vera Strychnou \\ South - West University "Neofit Rilski", Bulgaria \\ E-mail: verastrychnou@gmail.com
}

\begin{abstract}
This research was conducted to explore and compare the attitudes of Greek educators towards immigrant children and children with special educational needs, as well as to establish some social-demographic differences in Greek teachers' attitudes. The research tool used in this research was the questionnaire. The scale of answering was a five-degree Likert scale, and only one question was yes/no. The statistical program used for statistical analysis of the data was the IBM SPSS program. Descriptive statistics, correlation coefficients, and chi-square analysis were used. The sampling method used in the present research was the feasibility sampling, and even the homogeneity technique was used. In this research, all the participants were educators. The research sample consisted of 150 participants. Modern Greek schools contain to a large extent migrant students and students with special educational needs. Based on this research, there were found several similarities in Greek teachers'attitudes towards immigrant students and students with special educational needs, but there were also some differences. The most negative attitudes towards immigrant students were expressed overtly by the male Greek teachers, at 18-29 years old, married, with one child, teaching history in secondary education, with the period of educational experience of 11-20 years, and the most negative attitudes towards the students with special educational needs were expressed overtly by the female Greek teachers, with $P h D$, in bad or very good economic situation, divorced, teaching in primary school for more than 10 years at school. The Greek school, although it is a "mosaic of students" with different educational, cognitive, political, social, economic, historical, linguistic and cultural specifics, insists on its monocultural orientation, the rejection of diversity, isolation, and stereotypes. Given these results, it is necessary in the future to explore the effective ways to reduce these perceptions, if not destroy them.
\end{abstract}

Keywords: educators, Greek schools, migrant students, racism, social attitudes, students with special educational needs.

\section{Introduction}

Nowadays, it is common for school classes to have children with special educational needs, as well as immigrant children. Although learning difficulties were unknown to the Greek educational system up to the 1960 s, it is now a cutting-edge issue, so more and more educators familiarize 
with special education (Labropoulou \& Panteliadou, 2000). On the other hand, it is a fact that a very large number of immigrants are staying in Greece, which also requires Greek schools to take into account interculturalism.

\section{Theoretical Part}

\section{Similarities in the Attitudes towards Students with Special Educational Needs and Immigrant Students}

The attitudes towards students with special educational needs and immigrant students are very similar. The main similarity is the fact that these students are often treated with suspicion, racism, stereotypes and devaluation (Soulis, 2008).

The second similarity is that the teachers are often not properly informed and do not know how to effectively help these children learn, develop their knowledge, skills and talents (ZoniouSideri, 2011). It has been found that very few teachers are familiarized with special education and intercultural education. Indeed, according to Pavlis (2016), several teachers report that they lack the appropriate skills and time to effectively help these children.

Another similarity is the fact that the teachers try to have friendly relations with the parents of immigrant children and children with special educational needs and to regularly inform them about their progress (Charavitsidis, 2009; Dimakos \& Tasiopoulou, 2003; Kalyva \& Agaliotis, 2009).

\section{Differences in the Attitudes towards Students with Special Educational Needs and Immigrant Students}

Despite the many similarities between the attitudes towards students with special educational needs and migrant students, there are some differences. The first difference is the fact that the teachers appear a little more positive about integrating children with special educational needs into school, although the majority of them think that they should only be included in special classes (Batsiou, Bebetsos, Panteli, \& Antoniou, 2008).

According to Halios and Pantazis (2012), male teachers are more positive about supporting foreign children with learning disabilities. Thus, male teachers consider, to a greater extent than women, that they have some support from relevant structures (such as school counselors).

It has also been established that the more and better studies teachers have, the more positive attitudes they have towards diversity. Also, age plays an important role as teachers with less than 35 years of age have a more positive attitude towards migrant students and students with special educational needs (Padeliadou \& Lambropoulou, 1997; Pavlis, 2016).

Finally, it has been shown that teachers' perceptions regarding the attendance of children with disabilities in the classroom can be adversely affected when some classmates reject and stigmatize them (McLeskey \& Waldron, 2002).

Based on these research findings and theoretical assumptions, a hypothesis has been formulated that Greek teachers would have more positive attitudes and perceptions towards students with special educational needs than towards migrant students, while some socio-demographic characteristics such as gender and age would be related to their views.

\section{Research Aim}

The aim of the research was to explore and compare the attitudes of Greek educators towards immigrant children and children with special educational needs, as well as to establish some social-demographic differences in Greek teachers' attitudes. 


\section{General Background}

The type of the research that was conducted is the quantitative. As far as concerned the scope of the research, this research focuses to investigate socio-demographic differences and the attitudes of Greek educators towards children with special educational needs and migrant children.

Between February and March 2018, the participants were informed in detail of their voluntary participation in the study and its purpose, so their informed consent was given. In March 2018, the questionnaires were constructed to be used to conduct the survey. During March-May 2018 the questionnaires were completed by the participants, and then the statistical analysis of the data started. The questionnaires were distributed between March and May 2018. The participants were first informed orally about the purpose and objectives of the survey, as well as their anonymity, and after agreeing to participate in the study, they were given the questionnaires to respond to them.

\section{Participants}

The sampling method used in the present research was the feasibility sampling, and even the homogeneity technique was used. In this research, all the participants were educators. The research sample consisted of 150 participants.

Table 1. Frequencies of socio-demographic differences in the sample of Greek teachers.

\begin{tabular}{cccc}
\hline Social categories & Type of social category & N & Percentage \\
\hline \multirow{2}{*}{ Gender } & Male & 70 & 46.7 \\
& Female & 80 & 53.3 \\
\hline \multirow{3}{*}{ Age group } & 18-29 years old & 8 & 5.3 \\
& 30-40 years old & 55 & 36.7 \\
& $41-50$ years old & 65 & 43.3 \\
Educational level & $51-60$ years old & 22 & 14.7 \\
& Postgraduate studies & 117 & 78 \\
\hline \multirow{3}{*}{ Economic situation } & PhD & 33 & 22 \\
\hline \multirow{2}{*}{ Family situation } & Very good & 4 & 2.7 \\
& Good & 86 & 57.3 \\
& Modest & 54 & 36 \\
& Bad & 6 & 4 \\
\hline Number of children & Married & 99 & 66 \\
& Single & 41 & 27.3 \\
& Divorced & 10 & 6.7 \\
\hline & No child & 80 & 53.3 \\
& One child & 42 & 28 \\
& Two children & 27 & 18 \\
& Three children & 1 & 0.7 \\
\hline
\end{tabular}


Stavroula-Vera STRYCHNOU. Similarities and differences in attitudes of Greek educators towards students with special educationa needs and migrant students: Social-demographic differences

36

\begin{tabular}{cccc}
\hline \multirow{2}{*}{ Social categories } & Type of social category & N & Percentage \\
\hline \multirow{3}{*}{ Place of residence } & City & 125 & 83.3 \\
& Province & 17 & 11.3 \\
& Village & 8 & 5.3 \\
\hline \multirow{3}{*}{ Classroom of teaching } & Primary & 29 & 19.3 \\
& Secondary & 65 & 43.3 \\
& Lyceum & 56 & 37.3 \\
\hline \multirow{3}{*}{ Years of teaching } & $1-5$ years & 24 & 16 \\
& $6-10$ years & 71 & 47.3 \\
& $11-20$ years & 45 & 30 \\
Teaching courses on & $21-30$ years & 10 & 6.7 \\
& Literature & 98 & 65.3 \\
& Greek language & 6 & 4 \\
\hline
\end{tabular}

As shown in Table 1, most of the survey participants were women, aged 41-50 years old, with postgraduate studies, good financial status, married without children, staying in town, and teaching mainly for 6-10 years, literature, in secondary classes.

\section{Data Collection}

The research tool used in this research was the questionnaire. The reasons for choosing this research tool are (Dafermos, 2011): it can be delivered and completed without the presence of the researcher, it is easily analyzed, low cost, a large number of data is collected in a relatively short time, and it ensures the anonymity of the participants.

The questionnaire that was used in this research was created by the researcher on the basis of some sources (Angelakos, et al., 2008; Athanasiou, 2001; Batsiou et al., 2008; Cassimos, Polychronopoulou, Tripsianis, \& Syriopoulou-Delli, 2015; Charavitsidis, 2009; Dimakos \& Tasiopoulou, 2003; Kalyva \& Agaliotis, 2009; Kasimati, 2006; Panteliadou \& Lambropoulou, 2000; Papazoi, 2016; Patsidou, 2010; Vaporidi, Kokaridas \& Krommydas, 2005; Vassileiou \& Charitaki, 2016; ZoniouSideri \& Vlachou, 2006). The teachers were asked the following questions:

If the immigrant children should not be in the classroom with the rest of the children, but must be in specially formed classrooms;

If the immigrant students tend to do only with other immigrant students and not with native students;

- If the teachers felt awkward when they taught immigrant students;

- If the immigrant students should not exceed a percentage of $30 \%$ of students in one class;

- If the teachers tended to be much more lenient when evaluating the work of immigrant students;

- If they were forced to "reduce" their course level so that immigrant students can also attend to it;

- If the children with special educational needs should be taught in separate school classes by the other children;

- If the kids with special educational needs were rarely developing friendships with other peers; 
- If they were a lot flexible in grades of students with special educational needs;

- If they managed quite effectively situations of disapproval of a child with special educational needs from his / her classmates.

The scale of answering was a five-degree Likert scale in which teachers tick $\mathrm{X}$ in a response depending on the degree to which they agree or disagree (All, Little, Moderate, A lot, Very much).

Besides, the teachers answered if they had been trained in special education - yes/no. Most of them $(N=82,54.7 \%)$ were trained in special education, whilst the others $(N=68,45.3 \%)$ were not trained in special education.

It is worth noting that Cronbach's alpha for teachers was .243 for both questions regarding immigrant students and students with special educational needs (.273 only for immigrant students and .018 only for students with special educational needs), so it was very low, and the questionnaire was regarded as a survey questionnaire, so the answers on each question were analyzed separately without computing a test score.

\section{Data Analysis}

The statistical program used for statistical analysis of the data was the IBM SPSS program and in particular version 22. Descriptive statistics were used for the presentation and summary of the data, correlation coefficients for the research of relations between variables, and chisquare analysis for group differences on the nominal or ordinal measurement level. Because it is the case of violation of some assumptions for applying chi-square test - the expected counts less than 5 should not be more than $20 \%$ and the minimum expected count should not be less than 1, the value of Likelihood ratio was applied as a more appropriate measure for association between the variables than the value of chi-square test, as Özdemir and Eyduran (2005) recommend.

\section{Results of Research}

\section{Results from the Survey Questionnaire about Teachers' Attitudes towards Migrant Students}

As far as concerned the attitudes towards migrant students, the majority of the teachers (51.3\%) stated that they agreed moderate with the view that the immigrant children should not be in the classroom with the rest of the children but must be in specially formed classrooms.

Also, $47.3 \%$ of the teachers agreed a lot with the view that the immigrant students tended to do only with other immigrant students and not with native students. Other $20.7 \%$ of the studied Greek teachers agreed very much with this view.

Moreover, it is noteworthy that $57.3 \%$ of the sample felt very awkward when they taught the immigrant children, $26.7 \%$ of the sample felt moderately awkward when they taught the immigrant students, and $16 \%$ felt very much awkward.

Furthermore, $56 \%$ of the sample agreed moderately with the view that the immigrant children should not exceed a percentage of $30 \%$ of students in one class and at the same time, $34.7 \%$ of the studied Greek teachers agreed a lot with the view that the immigrant students should not exceed a percentage of $30 \%$ of students in one class and at the same time, and $9.3 \%$ agreed very much with this statement.

Also, $77.3 \%$ of teachers tended to be much more lenient when evaluating the work of immigrant students, and $21.3 \%$ of them - very much.

Besides, $72.7 \%$ of teachers stated that they were forced to "reduce" a lot their course level so that the immigrant students could also attend to it, and $18.7 \%$ of them reduced their course content very much for the same reason. 
Stavroula-Vera STRYCHNOU. Similarities and differences in attitudes of Greek educators towards students with special educational needs and migrant students: Social-demographic differences

Gender differences

A chi-square test was performed for gender differences and a statistically significant difference was found between the frequencies of male and female teachers who stated that the immigrant children should not be in the classroom with the rest of the children, but must be in specially formed classrooms $\left(\chi^{2}(4, N=150)=29.967, p<.001\right.$; Likelihood ratio $=36.057, p<.001$; $\mathrm{Phi}=0.447)$. More male Greek teachers $(22.8 \%$ of male teachers) than female Greek teachers $(8.8 \%$ of female teachers) stated that the immigrant children should not be in the classroom with the rest of the children but must be in specially formed classrooms.

A chi-square test was performed, and a statistically significant difference was found between the frequencies of male and female teachers who stated that the immigrant students tended to do only with other immigrant students and not with native students $\left(\chi^{2}(3, N=150)=16.134\right.$, $p=.001$; Likelihood ratio $=19.991, p<.001 ; \mathrm{Phi}=0.328)$. More male Greek teachers $(77.1 \%$ of male teachers) than female Greek teachers (60\% of female teachers) stated that the immigrant students tended to do only with other immigrant students and not with native students.

There was not any statistically significant difference between the frequencies of male and female teachers who stated that they felt awkward when they taught the immigrant students $\left(\chi^{2}(2, N=150)=0.984, p=.611\right.$; Likelihood ratio $\left.=0.990, p=.610 ; \mathrm{Phi}=0.081\right)$, neither who stated that the immigrant students should not exceed a percentage of $30 \%$ of students in one class $\left(\chi^{2}(2, N=150)=0.854, p=.653\right.$; Likelihood ratio $=0.855, p=.652$; Phi $\left.=0.075\right)$, neither who stated that they tended to be much more lenient when evaluating the work of immigrant students $\left(\chi^{2}(1, N=150)=0.729, p=.393 ;\right.$ Likelihood ratio $=0.734, p=.392$; Phi $\left.=0.070\right)$.

A statistically significant difference was found between the frequencies of male and female teachers who stated that they were forced to "reduce" their course level so that the immigrant students could also attend to it $\left(\chi^{2}(2, N=150)=14.926, p=.001\right.$; Likelihood ratio $=19.212, p<.001$; $\mathrm{Phi}=0.318)$. More female Greek teachers (all of them) than male Greek teachers $(84.3 \%$ of male teachers) stated that they were forced to "reduce" their course level so that the immigrant students could also attend to it.

Age differences

Also, a statistically significant difference was found between the frequencies of the age groups of teachers who stated that the immigrant children should not be in the classroom with the rest of the children but must be in specially formed classrooms $\left(\chi^{2}(12, N=150)=110.527, p<.001\right.$; Likelihood ratio $=81.895, p<.001 ; \mathrm{Phi}=0.858$ ). The studied Greek teachers in the age group of $41-50$ years old the most frequently considered ( $26.2 \%$ of them) that the immigrant children should not be in the classroom with the rest of the children but must be in specially formed classrooms.

A statistically significant difference was found between the frequencies of the age groups of teachers who stated that the immigrant students tended to do only with other immigrant students and not with native students $\left(\chi^{2}(9, N=150)=24.878, p=.003\right.$; Likelihood ratio $=29.216, p=.001$; $\mathrm{Phi}=0.407)$. The studied Greek teachers in the age group of 18-29 years old the most frequently considered (all of them) that the immigrant students tended to do only with other immigrant students and not with native students.

A statistically significant difference was found between the frequencies of the age groups of teachers who stated that they felt awkward when they taught the immigrant students $\left(\chi^{2}(6, N=150)=28.772, p<.001\right.$; Likelihood ratio $\left.=30.184, p<.001 ; \mathrm{Phi}=0.438\right)$. The studied Greek teachers in the age group of 18-29 years old the most frequently considered (all of them) that they felt awkward when they taught the immigrant students.

A statistically significant difference was found between the frequencies of the age groups of teachers who stated that the immigrant students should not exceed a percentage of $30 \%$ of students in one class $\left(\chi^{2}(6, N=150)=12.859, p=.045\right.$; Likelihood ratio $=15.715, p=.015$; Phi $=0.293$ ). The studied Greek teachers in the age group of 51-60 years old the most frequently considered $(68.2 \%$ of them) that the immigrant students should not exceed a percentage of $30 \%$ of students in one class. 
A statistically significant difference was found between the frequencies of the age groups of teachers who stated that they tended to be very much more lenient when evaluating the work Vol. 12, No. 1, 2018 of immigrant students $\left(\chi^{2}(3, N=150)=23.486, p<.001\right.$; Likelihood ratio $=21.078, p<.001$; $\mathrm{Phi}=0.398)$. The studied Greek teachers in the age group of 51-60 years old the most frequently considered (54.5\% of them) that they tended to be very much more lenient when evaluating the work of immigrant students.

A statistically significant difference was found between the frequencies of the age groups of teachers who stated that they were forced to "reduce" their course level so that the immigrant students could also attend to it $\left(\chi^{2}(6, N=150)=37.963, p<.001\right.$; Likelihood ratio $=39.120$, $p<.001 ; \mathrm{Phi}=0.506)$. The studied Greek teachers in the age groups of $41-50$ years old (all of them) and 51-60 years old (all of them) the most frequently considered that they were forced to "reduce" their course level so that the immigrant students could also attend to it.

\section{Educational differences}

Another chi-square test was performed, and a statistically significant difference was found between the frequencies of teachers with different educational level who stated that the immigrant children should not be in the classroom with the rest of the children but must be in specially formed classrooms $\left(\chi^{2}(4, N=150)=27.168, p<.001\right.$; Likelihood ratio $=32.226, p<.001$; Phi $\left.=0.426\right)$. More Greek teachers with postgraduate studies (19.7\% of them) than Greek teachers with $\mathrm{PhD}$ (no one of them) stated that the immigrant children should not be in the classroom with the rest of the children but must be in specially formed classrooms.

A statistically significant difference was found between the frequencies of teachers with different educational level who stated that the immigrant students tended to do only with other immigrant students and not with native students $\left(\chi^{2}(3, N=150)=17.435, p=.001\right.$; Likelihood ratio $=17.597, p=.001 ; \mathrm{Phi}=0.341)$. More Greek teachers with $\mathrm{PhD}(78.8 \%$ of them $)$ than Greek teachers with postgraduate studies (65\% of them) stated that the immigrant students tended to do only with other immigrant students and not with native students.

A statistically significant difference was found between the frequencies of teachers with different educational level who stated that they felt awkward when they taught the immigrant students $\left(\chi^{2}(2, N=150)=11.558, p=.003\right.$; Likelihood ratio $\left.=13.541, p=.001 ; \mathrm{Phi}=0.278\right)$. More Greek teachers with $\mathrm{PhD}$ (93.9\% of them) than Greek teachers with postgraduate studies (67.5\% of them) stated that they felt awkward when they taught the immigrant students.

A statistically significant difference was found between the frequencies of teachers with different educational level who stated that the immigrant students should not exceed a percentage of $30 \%$ of students in one class $\left(\chi^{2}(2, N=150)=60.714, p<.001\right.$; Likelihood ratio $=56.360, p<.001$; $\mathrm{Phi}=0.636)$. More Greek teachers with $\mathrm{PhD}(81.8 \%$ of them $)$ than Greek teachers with postgraduate studies (33.3\% of them) stated that the immigrant students should not exceed a percentage of $30 \%$ of students in one class.

A statistically significant difference was found between the frequencies of teachers with different educational level who stated that they tended to be very much more lenient when evaluating the work of immigrant students $\left(\chi^{2}(1, N=150)=8.700, p=.003\right.$; Likelihood ratio $=7.328$, $p=.007$; Phi $=0.242)$. More Greek teachers with $\mathrm{PhD}(40.6 \%$ of them) than Greek teachers with postgraduate studies (16.4\% of them) stated that they tended to be very much more lenient when evaluating the work of immigrant students.

A statistically significant difference was found between the frequencies of teachers with different educational level who stated that they were forced to "reduce" their course level so that the immigrant students could also attend to it $\left(\chi^{2}(2, N=150)=14.332, p=.001\right.$; Likelihood ratio = $15.002, p=.001 ; \mathrm{Phi}=0.311)$. More Greek teachers with $\mathrm{PhD}$ (all of them) than Greek teachers with postgraduate studies ( $90.5 \%$ of them) stated that they were forced to "reduce" their course level so that the immigrant students could also attend to it. 
Stavroula-Vera STRYCHNOU. Similarities and differences in attitudes of Greek educators towards students with special educational needs and migrant students: Social-demographic differences

Differences in economic situation

However, any statistically significant differences were not found between the frequencies of the answers of Greek teachers with different economic situation who stated that the immigrant children should not be in the classroom with the rest of the children, but must be in specially formed classrooms $\left(\chi^{2}(12, N=150)=9.492, p=.660\right.$; Likelihood ratio $=11.421, p=.493$; Phi $\left.=0.252\right)$, neither who stated that the immigrant students tended to do only with other immigrant students and not with native students $\left(\chi^{2}(9, N=150)=7.484, p=.587\right.$; Likelihood ratio $=8.466, p=.488$; Phi $=0.223)$, neither who stated that they felt awkward when they taught the immigrant students $\left(\chi^{2}(6, N=150)=4.732, p=.579\right.$; Likelihood ratio $=6.041, p=.419 ;$ Phi $\left.=0.178\right)$, neither who stated that the immigrant students should not exceed a percentage of $30 \%$ of students in one class $\left(\chi^{2}(6, N=150)=3.262, p=.775 ;\right.$ Likelihood ratio $\left.=4.108, p=.662 ; \mathrm{Phi}=0.147\right)$.

There was a statistically significant difference between the frequencies of the answers of Greek teachers with different economic situation who stated that they tended to be very much more lenient when evaluating the work of immigrant students $\left(\chi^{2}(3, N=150)=11.242, p=.010\right.$; Likelihood ratio $=10.771, p=.013 ; \mathrm{Phi}=0.276)$. More Greek teachers in bad economic situation $(66.7 \%$ of them) tended to be very much more lenient when evaluating the work of immigrant students than the studied Greek teachers in moderate ( $13 \%$ of them), good ( $25 \%$ of them) and very good (no one of them, but they all just tended to be more lenient when evaluating the work of immigrant students) economic situations.

There was a statistically significant difference between the frequencies of the answers of Greek teachers with different economic situation who stated that they were forced to "reduce" their course level so that the immigrant students could also attend to it $\left(\chi^{2}(6, N=150)=14.572, p=.024\right.$; Likelihood ratio $=13.329, p=.038 ; \mathrm{Phi}=0.314)$. More Greek teachers in bad economic situation (all of them) and in very good economic situation (all of them) tended to "reduce" their course level so that the immigrant students could also attend to it than the studied Greek teachers in moderate ( $87.1 \%$ of them), and good ( $95.2 \%$ of them) economic situations.

\section{Family status differences}

Furthermore, a statistically significant difference was found between the frequencies of the answers of Greek teachers with different family situation who stated that the immigrant children should not be in the classroom with the rest of the children but must be in specially formed classrooms $\left(\chi^{2}(8, N=150)=15.522, p=.050\right.$; Likelihood ratio $=16.300, p=.038$; Phi $\left.=0.322\right)$. The married Greek teachers (18.2\% of them) more frequently than single (12.2\% of them) and divorced (no one of them) teachers stated that the immigrant children should not be in the classroom with the rest of the children but must be in specially formed classrooms. Of course, the number of the studied divorced Greek teachers was not enough to make categorical conclusions regarding them.

A statistically significant difference was found between the frequencies of the answers of Greek teachers with different family situation who stated that the immigrant students tended to do only with other immigrant students and not with native students $\left(\chi^{2}(6, N=150)=27.143\right.$, $p<.001$; Likelihood ratio $=28.172, p<.001 ; \mathrm{Phi}=0.425)$. The divorced Greek teachers (all of them) more frequently than single ( $83 \%$ of them) and married (58.6\% of them) teachers stated that the immigrant students tended to do only with other immigrant students and not with native students.

There was not any statistically significant difference between the frequencies of the answers of Greek teachers with different family situation who stated that they felt awkward when they taught the immigrant students $\left(\chi^{2}(4, N=150)=4.662, p=.324\right.$; Likelihood ratio $=7.215, p=.125$; Phi $=0.176$ ).

A statistically significant difference was found between the frequencies of the answers of Greek teachers with different family situation who stated that the immigrant students should not exceed a percentage of $30 \%$ of students in one class $\left(\chi^{2}(4, N=150)=9.912, p=.042\right.$; Likelihood ratio $=10.057, p=.039 ; \mathrm{Phi}=0.257)$. The divorced Greek teachers $(60 \%$ of them) stated that the immigrant students should not exceed a percentage of $30 \%$ of students in one class more frequently than single ( $24.4 \%$ of them) and married (50.5\% of them) teachers. 
A statistically significant difference was found between the frequencies of the answers of Greek teachers with different family situation who stated that they tended to be very much more Vol. 12, No. 1, 2018 lenient when evaluating the work of immigrant students $\left(\chi^{2}(2, N=150)=17.425, p<.001\right.$; Likelihood ratio $=14.557, p=.001 ; \mathrm{Phi}=0.343)$. The divorced Greek teachers $(70 \%$ of them) stated that they tended to be very much more lenient when evaluating the work of immigrant students more frequently than single ( $26.8 \%$ of them) and married ( $14.4 \%$ of them) teachers.

A statistically significant difference was found between the frequencies of the answers of Greek teachers with different family situation who stated that they were forced to "reduce" their course level so that the immigrant students could also attend to it $\left(\chi^{2}(4, N=150)=19.232, p=\right.$ .001 ; Likelihood ratio $=15.147, p=.004 ; \mathrm{Phi}=0.360)$. The divorced Greek teachers (all of them) stated that they were forced to "reduce" their course level so that the immigrant students could also attend to it more frequently than single (95.1\% of them) and married (90.7\% of them) teachers.

Differences, according to the number of own children

Also, a statistically significant difference was found between the frequencies of the answers of Greek teachers with different number of children who stated that the immigrant children should not be in the classroom with the rest of the children but must be in specially formed classrooms $\left(\chi^{2}(12, N=150)=67.011, p<.001\right.$; Likelihood ratio $=83.921, p<.001 ;$ Phi $\left.=0.668\right)$. The Greek teachers with one child ( $31 \%$ of them) more frequently considered that the immigrant children should not be in the classroom with the rest of the children but must be in specially formed classrooms than the Greek teachers without children (12.4\% of them) and the Greek teachers with two or three children (no one of both groups of teachers). Of course, the number of the Greek teachers with three children was not enough to make categorical conclusions regarding them.

Another chi-square test was performed, and a statistically significant difference was found between the frequencies of the answers of Greek teachers with different number of children who stated that the immigrant students tended to do only with other immigrant students and not with native students $\left(\chi^{2}(9, N=150)=35.436, p<.001\right.$; Likelihood ratio $\left.=42.327, p<.001 ; \mathrm{Phi}=0.486\right)$. The studied Greek teacher with three children and the Greek teachers without children $(82.5 \%$ of them) more frequently considered that the immigrant students tended to do only with other immigrant students and not with native students than the Greek teachers with one child (61.9\% of them) and the Greek teachers with two children (33.3\% of them).

There was not any statistically significant difference between the frequencies of the answers of Greek teachers with different number of children who stated that they felt awkward when they taught the immigrant students $\left(\chi^{2}(6, N=150)=1.116, p=.981\right.$; Likelihood ratio $=1.485, p=.960$; $\mathrm{Phi}=0.086)$, neither who stated that the immigrant students should not exceed a percentage of $30 \%$ of students in one class $\left(\chi^{2}(6, N=150)=9.003, p=.173\right.$; Likelihood ratio $=9.325, p=.156$; $\mathrm{Phi}=0.245)$.

A statistically significant difference was found between the frequencies of the answers of Greek teachers with different number of children who stated that they tended to be very much more lenient when evaluating the work of immigrant students $\left(\chi^{2}(3, N=150)=13.435, p=.004\right.$; Likelihood ratio $=14.562, p=.002$; Phi $=0.301)$. The studied Greek teachers without children (33.3\% of them) more frequently considered that they tended to be very much more lenient when evaluating the work of immigrant students than the Greek teachers with one child (9.5\% of them), the Greek teachers with two children (7.4\% of them), and the studied Greek teacher with three children (who just tended to be more lenient when evaluating the work of immigrant students).

A statistically significant difference was found between the frequencies of the answers of Greek teachers with different number of children who stated that they were forced to "reduce" their course level so that the immigrant students could also attend to it $\left(\chi^{2}(6, N=150)=19.466\right.$, $p=.003$; Likelihood ratio $=18.859, p=.004$; Phi $=0.363$ ). The studied Greek teacher with three children, the studied Greek teachers without children (97.4\% of them) and the teachers with two children ( $96.3 \%$ of them) more frequently considered that they were forced to "reduce" their course level so that the immigrant students could also attend to it than the Greek teachers with one child (80.9\% of them). 
Stavroula-Vera STRYCHNOU. Similarities and differences in attitudes of Greek educators towards students with special educational needs and migrant students: Social-demographic differences

Differences in place of residence

A statistically significant difference was found between the frequencies of the answers of Greek teachers with different place of residence who stated that the immigrant children should not be in the classroom with the rest of the children but must be in specially formed classrooms $\left(\chi^{2}(8, N=\right.$ $150)=30.184, p<.001$; Likelihood ratio $=31.148, p<.001$; Phi $=0.449)$. The Greek teachers who lived in the cities ( $18.4 \%$ of them) more frequently considered that the immigrant children should not be in the classroom with the rest of the children but must be in specially formed classrooms than the Greek teachers who lived in province and villages (no one of both groups of teachers). The most immigrants usually prefer to go in regional cities instead of villages or province to find better opportunities for gain their living and to arrange the administrative formalities regarding their stay in the country. The studied Greek teachers in province and villages may not have a lot of contacts with immigrant students.

A statistically significant difference was found between the frequencies of the answers of Greek teachers with different place of residence who stated that the immigrant students tended to do only with other immigrant students and not with native students $\left(\chi^{2}(6, N=150)=16.702\right.$, $p=.010$; Likelihood ratio $=16.926, p=.010 ; \mathrm{Phi}=0.334)$. The Greek teachers who lived in province (82.4\% of them) more frequently considered that the immigrant students tended to do only with other immigrant students and not with native students than the Greek teachers who lived in cities ( $66.4 \%$ of them) and in villages ( $72.5 \%$ of them).

There was not any statistically significant difference between the frequencies of the answers of Greek teachers with different place of residence who stated that they felt awkward when they taught the immigrant students $\left(\chi^{2}(4, N=150)=5.452, p=.244\right.$; Likelihood ratio $=7.459, p=$ .114 ; Phi $=0.191)$, neither who stated that they tended to be very much more lenient when evaluating the work of immigrant students $\left(\chi^{2}(2, N=150)=1.609, p=.447\right.$; Likelihood ratio $=1.452$, $p=.484$; Phi $=0.104)$, neither who stated that they were forced to "reduce" their course level so that the immigrant students could also attend to it $\left(\chi^{2}(4, N=150)=4.401, p=.354\right.$; Likelihood ratio $=5.730, p=.220 ; \mathrm{Phi}=0.172$ ).

A statistically significant difference was found between the frequencies of the answers of Greek teachers with different place of residence who stated that the immigrant students should not exceed a percentage of $30 \%$ of students in one class $\left(\chi^{2}(4, N=150)=22.186, p<.001\right.$; Likelihood ratio $=18.502, p=.001$; Phi $=0.385)$. The Greek teachers who lived in villages $(87.5 \%$ of them $)$ more frequently considered that the immigrant students should not exceed a percentage of $30 \%$ of students in one class than the Greek teachers who lived in cities (38.4\% of them) and in province (64.7\% of them).

\section{Differences in types of schools}

A statistically significant difference was found between the frequencies of the answers of Greek teachers teaching in different classrooms in different types of schools who stated that the immigrant children should not be in the classroom with the rest of the children, but must be in specially formed classrooms $\left(\chi^{2}(8, N=150)=17.698, p=.024\right.$; Likelihood ratio $=23.706, p=.003$; $\mathrm{Phi}=0.343)$. More Greek teachers who taught in secondary school $(21.5 \%$ of them $)$ considered that the immigrant children should not be in the classroom with the rest of the children but must be in specially formed classrooms than the Greek teachers who taught in primary school (no one of them) or in lyceum ( $16.1 \%$ of them).

A statistically significant difference was found between the frequencies of the answers of Greek teachers teaching in different classrooms in different types of schools who stated that the immigrant students tended to do only with other immigrant students and not with native students $\left(\chi^{2}(6, N=150)=15.795, p=.015 ;\right.$ Likelihood ratio $\left.=16.585, p=.011 ; \mathrm{Phi}=0.325\right)$. More Greek teachers who taught in primary school ( $86.2 \%$ of them) considered that the immigrant students tended to do only with other immigrant students and not with native students than the Greek teachers who taught in secondary school ( $66.2 \%$ of them) or in lyceum ( $60.8 \%$ of them). 
There was not any statistically significant difference between the frequencies of the answers of Greek teachers teaching in different classrooms in different types of schools who stated that they felt Vol. 12, No. 1, 2018 awkward when they taught the immigrant students $\left(\chi^{2}(4, N=150)=1.469, p=.832\right.$; Likelihood ratio $=1.522, p=.823$; Phi $=0.099)$, neither who stated that the immigrant students should not exceed a percentage of $30 \%$ of students in one class $\left(\chi^{2}(4, N=150)=1.015, p=.907\right.$; Likelihood ratio $=1.009, p=.908 ; \mathrm{Phi}=0.082$ ).

A statistically significant difference was found between the frequencies of the answers of Greek teachers teaching in different classrooms in different types of schools who stated that they tended to be very much more lenient when evaluating the work of immigrant students $\left(\chi^{2}(2, N=150)=25.101, p<.001 ;\right.$ Likelihood ratio $\left.=22.401, p<.001 ; \mathrm{Phi}=0.412\right)$. More Greek teachers who taught in primary school (55.2\% of them) considered that they tended to be very much more lenient when evaluating the work of immigrant students than the Greek teachers who taught in secondary school (17.2\% of them) or in lyceum (9.1\% of them).

A statistically significant difference was found between the frequencies of the answers of Greek teachers teaching in different classrooms in different types of schools who stated that they were forced to "reduce" their course level so that the immigrant students could also attend to it $\left(\chi^{2}(4, N=150)=39.465, p<.001\right.$; Likelihood ratio $\left.=35.527, p<.001 ; \mathrm{Phi}=0.516\right)$. More Greek teachers who taught in primary school (all of them) considered that they were forced to "reduce" their course level so that the immigrant students could also attend to it than the Greek teachers who taught in secondary school ( $96.9 \%$ of them) or in lyceum $(83.7 \%$ of them).

\section{Differences in teaching period}

A statistically significant difference was found between the frequencies of the answers of Greek teachers teaching for different number of years who stated that the immigrant children should not be in the classroom with the rest of the children but must be in specially formed classrooms $\left(\chi^{2}\right.$ $(12, N=150)=138.969, p<.001 ;$ Likelihood ratio $=116.925, p<.001 ; \mathrm{Phi}=0.963)$. More Greek teachers who taught for 11-20 years (35.6\% of them) considered that the immigrant children should not be in the classroom with the rest of the children but must be in specially formed classrooms than the Greek teachers who taught for $1-5$ years ( $4.2 \%$ of them), for $6-10$ years ( $8.5 \%$ of them), and for 21-30 years (no one of them).

A statistically significant difference was found between the frequencies of the answers of Greek teachers teaching for different number of years who stated that the immigrant students tended to do only with other immigrant students and not with native students $\left(\chi^{2}(9, N=150)=33.457\right.$, $p<.001$; Likelihood ratio $=39.707, p<.001$; Phi $=0.472)$. More Greek teachers who taught for 1120 years ( $80 \%$ of them) and for $21-30$ years ( $80 \%$ of them) considered that the immigrant students tended to do only with other immigrant students and not with native students than the Greek teachers who taught for $1-5$ years ( $75 \%$ of them), for $6-10$ years (56.3\% of them).

There was not any statistically significant difference between the frequencies of the answers of Greek teachers teaching for different number of years who stated that they felt awkward when they taught the immigrant students $\left(\chi^{2}(6, N=150)=9.848, p=.131\right.$; Likelihood ratio $=11.974$, $p=.063 ; \mathrm{Phi}=0.256)$, neither who stated that the immigrant students should not exceed a percentage of $30 \%$ of students in one class $\left(\chi^{2}(6, N=150)=8.754, p=.188\right.$; Likelihood ratio $=11.272$, $p=.080$; Phi $=0.242$ ).

A statistically significant difference was found between the frequencies of the answers of Greek teachers teaching for different number of years who stated that they tended to be very much more lenient when evaluating the work of immigrant students $\left(\chi^{2}(3, N=150)=15.481, p=.001\right.$; Likelihood ratio $=12.475, p=.006$; $\mathrm{Phi}=0.323)$. More Greek teachers who taught for $21-30$ years $(70 \%$ of them) considered that they tended to be very much more lenient when evaluating the work of immigrant students than the Greek teachers who taught for $1-5$ years (16.7\% of them), for $6-10$ years (15.9\% of them), and for $11-20$ years (22.2\% of them).

A statistically significant difference was found between the frequencies of the answers of Greek teachers teaching for different number of years who stated that they were forced to "reduce" their course level so that the immigrant students could also attend to it $\left(\chi^{2}(6, N=150)=68.378\right.$, 
$p<.001 ;$ Likelihood ratio $=53.967, p<.001 ; \mathrm{Phi}=0.680)$. More Greek teachers who taught for 1120 years (all of them), for 21-30 years (all of them) and for 6-10 years (98.5\% of them) considered that they were forced to "reduce" their course level so that the immigrant students could also attend to it than the Greek teachers who taught for $1-5$ years (58.3\% of them).

Differences in school subjects taught by the teachers

Any statistically significant difference was not found between the frequencies of the answers of Greek teachers teaching different school subjects who stated that the immigrant children should not be in the classroom with the rest of the children, but must be in specially formed classrooms $\left(\chi^{2}(8, N=150)=4.895, p=.769\right.$; Likelihood ratio $=6.262, p=.618$; Phi $\left.=0.181\right)$, neither who stated that the immigrant students tended to do only with other immigrant students and not with native students $\left(\chi^{2}(6, N=150)=5.420, p=.491\right.$; Likelihood ratio $=7.219, p=.301$; Phi $=0.190)$, neither who stated that they felt awkward when they taught the immigrant students $\left(\chi^{2}(4, N=150)=5.352, p=.253\right.$; Likelihood ratio $=5.167, p=.271$; Phi $\left.=0.189\right)$, neither who stated that they tended to be very much more lenient when evaluating the work of immigrant students $\left(\chi^{2}(2, N=150)=2.079, p=.354\right.$; Likelihood ratio $=3.343, p=.188$; Phi $\left.=0.119\right)$, neither who stated that they were forced to "reduce" their course level so that the immigrant students could also attend to it $\left(\chi^{2}(4, N=150)=3.213, p=.523\right.$; Likelihood ratio $=4.656, p=.324$; Phi $\left.=0.147\right)$.

There was a statistically significant difference between the frequencies of the answers of Greek teachers teaching different school subjects who stated that the immigrant students should not exceed a percentage of $30 \%$ of students in one class $\left(\chi^{2}(4, N=150)=19.115, p=.001\right.$; Likelihood ratio $=$ 24.692, $p<.001$; Phi $=0.357)$. More Greek teachers teaching history $(54.3 \%$ of them) considered that the immigrant students should not exceed a percentage of $30 \%$ of students in one class than the studied Greek teachers who taught literature (41.9\% of them) or Greek language (no one of them).

\section{Results from the Survey Questionnaire about Teachers'Attitudes towards Students with Special Educational Needs}

As far as concerned the attitudes towards students with special educational needs, $52 \%$ of teachers agreed little to the view that the students with special educational needs should be taught in separate school classes by the other children, and $9.3 \%$ of teachers did not agree at all with such a view.

In addition, the majority of the sample (41.3\%) agreed moderately that the students with special educational needs rarely were developing friendships with other peers, and $32 \%$ of the studied teachers agreed little with this statement.

Moreover, $52 \%$ of teachers said they were a lot flexible in grades of students with special educational needs, $41.3 \%$ said they were very much flexible, and only $6.7 \%$ were moderately flexible.

Finally, $49.3 \%$ of the sample managed quite effectively situations of disapproval of a child with special educational needs from his / her classmates and $40.7 \%$ of the teachers did it very much effectively.

Gender differences

A chi-square test was performed for gender differences and a statistically significant difference was found between the frequencies of male and female teachers who stated that the students with special educational needs should be taught in separate school classes by the other children $\left(\chi^{2}(4, N=150)=24.192, p<.001\right.$; Likelihood ratio $\left.=28.602, p<.001 ; \mathrm{Phi}=0.402\right)$. More female Greek teachers (36.3\% of them) than male Greek teachers ( $7.1 \%$ of them) stated that the students with special educational needs should be taught in separate school classes by the other children.

There was not any statistically significant difference between the frequencies of male and female teachers who stated that the students with special educational needs rarely were developing friendships with other peers $\left(\chi^{2}(3, N=150)=4.134, p=.247\right.$; Likelihood ratio $=4.147, p=.246$; $\mathrm{Phi}=0.166)$, neither who stated that they were very flexible in grades of students with special edu- 
cational needs $\left(\chi^{2}(2, N=150)=1.250, p=.535\right.$; Likelihood ratio $=1.251, p=.535$; Phi $\left.=0.091\right)$, Vol. 12, No. 1, 2018

neither who stated that they managed quite effectively situations of disapproval of a child with special educational needs from his/her classmates $\left(\chi^{2}(2, N=150)=3.556, p=.169\right.$; Likelihood ratio $=3.571, p=.168$; Phi $=0.154)$.

Age differences

A statistically significant difference was found between the frequencies of the age groups of teachers who stated that the students with special educational needs should be taught in separate school classes by the other children $\left(\chi^{2}(12, N=150)=41.957, p<.001\right.$; Likelihood ratio $=50.181$, $p<.001$; Phi $=0.529)$. The studied Greek teachers in the age group of $51-60$ years old $(31.8 \%$ of them) and in the age group of $41-50$ years old (30.8\% of them) the most frequently considered that the students with special educational needs should be taught in separate school classes by the other children.

A statistically significant difference was found between the frequencies of the age groups of teachers who stated that the students with special educational needs rarely were developing friendships with other peers $\left(\chi^{2}(9, N=150)=23.240, p=.006\right.$; Likelihood ratio $=26.257, p=.002$; $\mathrm{Phi}=0.394$ ). The studied Greek teachers in the age group of 18-29 years old (all of them) the most frequently considered that the students with special educational needs rarely were developing friendships with other peers.

There was not any statistically significant difference between the frequencies of the age groups of teachers who stated that they were very flexible in grades of students with special educational needs $\left(\chi^{2}(6, N=150)=12.928, p=.044\right.$; Likelihood ratio $=10.339, p=.111 ;$ Phi $\left.=0.294\right)$, neither who stated that they managed quite effectively situations of disapproval of a child with special educational needs from his/her classmates $\left(\chi^{2}(6, N=150)=10.258, p=.114\right.$; Likelihood ratio $=$ $10.533, p=.104 ; \mathrm{Phi}=0.262$ ).

\section{Educational differences}

A statistically significant difference was found between the frequencies of teachers with different educational level who stated that the students with special educational needs should be taught in separate school classes by the other children $\left(\chi^{2}(4, N=150)=13.770, p=.008\right.$; Likelihood ratio $=13.217, p=.010$; Phi $=0.303)$. More Greek teachers with $\mathrm{PhD}(42.4 \%$ of them $)$ than Greek teachers with postgraduate studies (17.1\% of them) stated that the students with special educational needs should be taught in separate school classes by the other children.

A statistically significant difference was found between the frequencies of teachers with different educational level who stated that the students with special educational needs rarely were developing friendships with other peers $\left(\chi^{2}(3, N=150)=57.798, p<.001\right.$; Likelihood ratio $=53.781, p<.001 ; \mathrm{Phi}=0.621)$. More Greek teachers with $\mathrm{PhD}(69.7 \%$ of them $)$ than Greek teachers with postgraduate studies ( $47.1 \%$ of them) stated that the students with special educational needs rarely were developing friendships with other peers.

A statistically significant difference was found between the frequencies of teachers with different educational level who stated that they were very flexible in grades of students with special educational needs $\left(\chi^{2}(2, N=150)=17.824, p<.001\right.$; Likelihood ratio $=15.531, p<.001$; Phi $\left.=0.345\right)$. More Greek teachers with postgraduate studies (97.4\% of them) than Greek teachers with $\mathrm{PhD}(78.8 \%$ of them) stated that they were very flexible in grades of students with special educational needs.

A statistically significant difference was found between the frequencies of teachers with different educational level who stated that they managed quite effectively situations of disapproval of a child with special educational needs from his/her classmates $\left(\chi^{2}(2, N=150)=9.839\right.$, $p=.007$; Likelihood ratio $=9.565, p=.008 ; \mathrm{Phi}=0.256$ ). More Greek teachers with postgraduate studies (93.2\% of them) than Greek teachers with $\mathrm{PhD}$ (78.8\% of them) stated that they managed quite effectively situations of disapproval of a child with special educational needs from his/her classmates. 
Stavroula-Vera STRYCHNOU. Similarities and differences in attitudes of Greek educators towards students with special educational needs and migrant students: Social-demographic differences

Differences in economic situation

There was a statistically significant difference between the frequencies of the answers of Greek teachers with different economic situation who stated that the students with special educational needs should be taught in separate school classes by the other children $\left(\chi^{2}(12, N=150)=29.787\right.$, $p=.003$; Likelihood ratio $=27.328, p=.007$; Phi $=0.446)$. More Greek teachers in bad economic situation (all of them) stated that the students with special educational needs should be taught in separate school classes by the other children than the studied Greek teachers in moderate (11.1\% of them), good (24.4\% of them) and very good ( $25 \%$ of them) economic situations.

There was a statistically significant difference between the frequencies of the answers of Greek teachers with different economic situation who stated that the students with special educational needs rarely were developing friendships with other peers $\left(\chi^{2}(9, N=150)=15.827, p=.071\right.$; Likelihood ratio $=18.176, p=.033 ; \mathrm{Phi}=0.325)$. More Greek teachers in very good economic situation $(75 \%$ of them) stated that the students with special educational needs rarely were developing friendships with other peers than the studied Greek teachers in bad (33\% of them), moderate (53.7\% of them), and good (51.2\% of them) economic situations.

There was not any statistically significant difference between the frequencies of the answers of Greek teachers with different economic situation who stated that they were very flexible in grades of students with special educational needs $\left(\chi^{2}(6, N=150)=1.524, p=.958\right.$; Likelihood ratio $=2.176, p=.903$; Phi $=0.101)$, neither who stated that they managed quite effectively situations of disapproval of a child with special educational needs from his/her classmates $\left(\chi^{2}(6, N=150)=2.010, p=.919 ;\right.$ Likelihood ratio $\left.=2.963, p=.813 ; \mathrm{Phi}=0.116\right)$.

\section{Family status differences}

There was not any statistically significant difference between the frequencies of the answers of Greek teachers with different family situation who stated that the students with special educational needs should be taught in separate school classes by the other children $\left(\chi^{2}(8, N=150)=9.400\right.$, $p=.310$; Likelihood ratio $=10.059, p=.261$; Phi $=0.250)$, neither who stated that they were very flexible in grades of students with special educational needs $\left(\chi^{2}(4, N=150)=11.579, p=.021\right.$; Likelihood ratio $=8.126, p=.087$; Phi $=0.278)$, neither who stated that they managed quite effectively situations of disapproval of a child with special educational needs from his/her classmates $\left(\chi^{2}(4, N=150)=8.479, p=.076\right.$; Likelihood ratio $=8.063, p=.089$; Phi $\left.=0.238\right)$.

A statistically significant difference was found between the frequencies of the answers of Greek teachers with different family situation who stated that the students with special educational needs rarely were developing friendships with other peers $\left(\chi^{2}(6, N=150)=17.378, p=.008\right.$; Likelihood ratio $=19.892, p=.003 ; \mathrm{Phi}=0.340)$. The divorced teachers $(80 \%$ of them $)$ more frequently than single ( $61 \%$ of them) and married Greek teachers $(45.4 \%$ of them) stated that the students with special educational needs rarely were developing friendships with other peers.

Differences, according to the number of own children

A statistically significant difference was found between the frequencies of the answers of Greek teachers with different number of children who stated that the students with special educational needs should be taught in separate school classes by the other children $\left(\chi^{2}(12, N=150)=25.832\right.$, $p=.011$; Likelihood ratio $=21.015, p=.050 ; \mathrm{Phi}=0.415)$. The Greek teachers without children ( $28.8 \%$ of them) more frequently considered that the students with special educational needs should be taught in separate school classes by the other children than the Greek teachers with one child (19\% of them), the Greek teachers with two children (7.4\% of them) and the studied Greek teacher with three children. Of course, the number of the Greek teachers with three children was not enough to make categorical conclusions regarding them.

A statistically significant difference was found between the frequencies of the answers of Greek teachers with different number of children who stated that the students with special educational needs rarely were developing friendships with other peers $\left(\chi^{2}(9, N=150)=35.749, p<.001\right.$; Likeli- 
hood ratio $=35.236, p<.001 ; \mathrm{Phi}=0.488)$. The Greek teachers with one child $(71.5 \%$ of them $)$ and the studied Greek teacher with three children more frequently did not consider that the students Vol. 12, No. 1, 2018 with special educational needs rarely were developing friendships with other peers than the Greek teachers without children ( $41.3 \%$ of them), and with two children (29.6\% of them).

There was not any statistically significant difference between the frequencies of the answers of Greek teachers with different number of children who stated that they were very flexible in grades of students with special educational needs $\left(\chi^{2}(6, N=150)=2.790, p=.835\right.$; Likelihood ratio $=3.206, p=.783$; Phi $=0.136)$, neither who stated that they managed quite effectively situations of disapproval of a child with special educational needs from his/her classmates $\left(\chi^{2}(6, N=150)=1.649, p=.949\right.$; Likelihood ratio $\left.=2.034, p=.917 ; \mathrm{Phi}=0.105\right)$.

\section{Differences in place of residence}

There was not any statistically significant difference between the frequencies of the answers of Greek teachers with different place of residence who stated that the students with special educational needs should be taught in separate school classes by the other children $\left(\chi^{2}(8, N=150)=12.372, p=.135\right.$; Likelihood ratio $=10.730, p=.217$; Phi $\left.=0.287\right)$.

There was a statistically significant difference between the frequencies of the answers of Greek teachers with different place of residence who stated that the students with special educational needs rarely were developing friendships with other peers $\left(\chi^{2}(6, N=150)=38.811, p<.001\right.$; Likelihood ratio $=32.903, p<.001 ; \mathrm{Phi}=0.509)$. The Greek teachers who lived in villages $(50 \%$ of them $)$ and in province (41.2\% of them) more frequently considered that the students with special educational needs rarely were developing friendships with other peers than the Greek teachers who lived in cities ( $4 \%$ of them).

There was a statistically significant difference between the frequencies of the answers of Greek teachers with different place of residence who stated that they were very flexible in grades of students with special educational needs $\left(\chi^{2}(4, N=150)=12.750, p=.013\right.$; Likelihood ratio $=10.687$, $p=.030$; Phi $=0.292)$. The Greek teachers who lived in cities $(96 \%$ of them) more frequently considered that they were very flexible in grades of students with special educational needs than the Greek teachers who lived in villages (87.5\% of them) and in province (76.4\% of them).

There was not any statistically significant difference between the frequencies of the answers of Greek teachers with different place of residence who stated that they managed quite effectively situations of disapproval of a child with special educational needs from his/her classmates $\left(\chi^{2}(4, N=150)=7.592, p=.108\right.$; Likelihood ratio $=7.383, p=.117$; Phi $\left.=0.225\right)$.

\section{Differences in types of schools}

A statistically significant difference was found between the frequencies of the answers of Greek teachers teaching in different classrooms in different types of schools who stated that the students with special educational needs should be taught in separate school classes by the other children $\left(\chi^{2}(8, N=150)=27.025, p=.001\right.$; Likelihood ratio $\left.=25.710, p=.001 ; \mathrm{Phi}=0.424\right)$. More Greek teachers who taught in primary school (51.7\% of them) considered that the students with special educational needs should be taught in separate school classes by the other children than the Greek teachers who taught in secondary school (13.9\% of them) or in lyceum (17.9\% of them).

There was not any statistically significant difference between the frequencies of the answers of Greek teachers teaching in different classrooms in different types of schools who stated that the students with special educational needs rarely were developing friendships with other peers $\left(\chi^{2}(6, N=150)=1.361, p=.968\right.$; Likelihood ratio $=1.399, p=.966$; Phi $\left.=0.095\right)$, neither who stated that they managed quite effectively situations of disapproval of a child with special educational needs from his/her classmates $\left(\chi^{2}(4, N=150)=7.130, p=.129\right.$; Likelihood ratio $=6.736$, $p=.151 ;$ Phi $=0.218$ ).

A statistically significant difference was found between the frequencies of the answers of Greek teachers teaching in different classrooms in different types of schools who stated that they were very flexible in grades of students with special educational needs $\left(\chi^{2}(4, N=150)=14.471\right.$, 
Stavroula-Vera STRYCHNOU. Similarities and differences in attitudes of Greek educators towards students with special educational needs and migrant students: Social-demographic differences

$p=.006 ;$ Likelihood ratio $=12.463, p=.014 ; \mathrm{Phi}=0.311)$. More Greek teachers who taught in lyceum $(98.2 \%$ of them) and in secondary school (95.4\% of them) considered that they were very flexible in grades of students with special educational needs than the Greek teachers who taught in primary school (79.3\% of them).

\section{Differences in teaching period}

A statistically significant difference was found between the frequencies of the answers of Greek teachers teaching for different number of years who stated that the students with special educational needs should be taught in separate school classes by the other children $\left(\chi^{2}(12, N=150)=45.263\right.$, $p<.001$; Likelihood ratio $=48.815, p<.001 ; \mathrm{Phi}=0.549)$. More Greek teachers who taught for 21-30 years (60\% of them) considered that the students with special educational needs should be taught in separate school classes by the other children than the Greek teachers who taught for 1-5 years (no one of them), for 6-10 years (29.6\% of them), and for $11-20$ years (15.6\% of them).

A statistically significant difference was found between the frequencies of the answers of Greek teachers teaching for different number of years who stated that the students with special educational needs rarely were developing friendships with other peers $\left(\chi^{2}(9, N=150)=17.080\right.$, $p=.047$; Likelihood ratio $=20.169, p=.017 ; \mathrm{Phi}=0.337)$. More Greek teachers who taught for 11-20 years ( $15.6 \%$ of them) and for $6-10$ years (12.7\% of them) considered that the students with special educational needs rarely were developing friendships with other peers than the Greek teachers who taught for 1-5 years (no one of them), and for 21-30 years (no one of them).

There was not any statistically significant difference between the frequencies of the answers of Greek teachers teaching for different number of years who stated that they were very flexible in grades of students with special educational needs $\left(\chi^{2}(6, N=150)=10.376, p=.110\right.$; Likelihood ratio $=10.933, p=.090$; Phi $=0.263)$, neither who stated that they managed quite effectively situations of disapproval of a child with special educational needs from his/her classmates $\left(\chi^{2}(6, N=150)=3.820, p=.701\right.$; Likelihood ratio $\left.=3.862, p=.695 ; \mathrm{Phi}=0.160\right)$.

Differences in school subjects taught by the teachers

There was a statistically significant difference between the frequencies of the answers of Greek teachers teaching different school subjects who stated that the students with special educational needs should be taught in separate school classes by the other children $\left(\chi^{2}(8, N=150)=16.475\right.$, $p=.036$; Likelihood ratio $=16.055, p=.042$; Phi $=0.331$ ). More Greek teachers teaching Greek language (33.3\% of them) considered that the students with special educational needs should be taught in separate school classes by the other children than the studied Greek teachers who taught literature (22.5\% of them) or history (21.7\% of them).

There was a statistically significant difference between the frequencies of the answers of Greek teachers teaching different school subjects who stated that the students with special educational needs rarely were developing friendships with other peers $\left(\chi^{2}(6, N=150)=11.888, p=.065\right.$; Likelihood ratio $=17.743, p=.007 ; \mathrm{Phi}=0.282)$. More Greek teachers teaching literature $(16.3 \%$ of them $)$ considered that the students with special educational needs rarely were developing friendships with other peers than the studied Greek teachers who taught Greek language (no one of them) or history (no one of them).

There was not any statistically significant difference between the frequencies of the answers of Greek teachers teaching different school subjects who stated that they were very flexible in grades of students with special educational needs $\left(\chi^{2}(4, N=150)=2.739, p=.602\right.$; Likelihood ratio $=3.115, p=.539$; $\mathrm{Phi}=0.135)$, neither who stated that they managed quite effectively situations of disapproval of a child with special educational needs from his/her classmates $\left(\chi^{2}(4, N=150)=3.829, p=.430\right.$; Likelihood ratio $\left.=4.401, p=.354 ; \mathrm{Phi}=0.160\right)$. 
Based on this research, there were found several similarities in Greek teachers' attitudes towards immigrant students and students with special educational needs, but there were also some differences.

More than a half of the studied Greek teachers expressed their negative attitudes towards immigrant students - they preferred that the immigrant children should not be in the classroom with the rest of the children, but must be in specially formed classrooms; they preferred the immigrant students not to exceed more than $30 \%$ of students in one class; they considered the immigrant students as willing to communicate only with other immigrant students; they felt awkward when they taught the immigrant students. At the same time, more than a half of the studied Greek teachers expressed their readiness for adjustment to the immigrant students' needs- the teachers tended to be more lenient when evaluating the work of immigrant students, and they reduced a lot their course level so that the immigrant students could also attend to it. As a conclusion, it could be stated that the Greek teachers' attitudes towards immigrant students are ambivalent.

The most negative attitudes towards immigrant students were expressed overtly by the male Greek teachers, at 18-29 years old, married, with one child, teaching history in secondary education, with the period of educational experience of 11-20 years.

More positive attitudes towards immigrant students were expressed overtly by the female Greek teachers, with bad economic situation, teaching in primary school for 6-10 years.

More than a half of the studied Greek teachers expressed their positive attitudes towards students with special educational needs - they considered that the students with special educational needs should not be taught in separate school classes by the other children, they believed in the abilities of students with special educational needs to develop friendships with other peers, they helped the students with special educational needs in the situations of disapproval from their classmates. Besides, more than a half of the studied Greek teachers expressed their readiness for adjustment to the students with special educational needs - they were flexible in grades of students with special educational needs.

The most negative attitudes towards the students with special educational needs were expressed overtly by the female Greek teachers, with $\mathrm{PhD}$, in bad or very good economic situation, divorced, teaching in primary school for more than 10 years at school.

The most positive attitudes towards the students with special educational needs were expressed overtly by the teachers from 30 to 40 years old, with one child, living in cities, teaching history in lyceum for less than 11 years at school.

Finally, the hypothesis was confirmed as it was found that Greek teachers had more positive perceptions and attitudes towards students with special educational needs than towards migrant students, while the socio-demographic characteristics were important factors determining their views.

So, for these two groups of students, it can be argued that their ugly social destiny is clearly identified by school. The Greek school insists on its monocultural orientation, the rejection of diversity, isolation, and stereotypes (Dimakos \& Tasiopoulou, 2003). Although in Greece intercultural education and inclusive education have evolved satisfactorily in relation to the past, they are still at a fairly early stage (Milesi, 2006). On the basis of all these, it is necessary to modernize the internal structure and functions of the Greek school (Gotovos, 2002), and for teachers, they need support, scientific information and guidance, as well as to acquire the necessary knowledge, skills, ways and means that can permit them to help the two categories of students (Tsiakalos, 2000).

\section{Conclusions}

The modern Greek school is a "mosaic of students" with different educational, cognitive, political, social, economic, historical, linguistic and cultural specifics. Although the social attitudes towards migrant students and students with special educational needs are somehow similar, the social attitudes towards immigrant students are a little more negative. However, both categories of students suffer racism, xenophobia, suspicion and marginalization (Brattou, 2016; Tsokalidou, 
Stavroula-Vera STRYCHNOU. Similarities and differences in attitudes of Greek educators towards students with special educational needs and migrant students: Social-demographic differences

2012). Given these results, it is necessary in the future to explore the effective ways to reduce these perceptions, if not destroy them. It is necessary for all of us to realize that diversity unites people, that education must abolish all sorts of racist attitudes and stereotypes, and that the "different" is not something that must scare us, but a new unexplored world.

\section{Acknowledgements}

The author would like to express a sincere thanks to the participants in the research for their cooperation.

\section{References}

Angelakos, K., Gotovos, A.E., Iosif, I.S., Kizilyürek, N., Koulouri, C., Myaris, G.K., Noutsos, P., Papadakis, G., Papaleodiou, L., Sokratous, G.N., Tsafos, V., Charamis, P., \& Charitidou, G. (2008). Diversity and education, the philology and pedagogical challenges of multiculturalism. Edited by Iosif, I.S., \& Sokratous, G. N. Athens: Papazisis.

Athanasiou, L. (2001). Problems of intercultural approach to education in Greece. Intercultural Education, 1, $15-25$

Batsiou, S., Bebetsos, S., Panteli, P., \& Antoniou, P. (2008). Attitudes and intention of Greek and Cypriot primary education teachers towards teaching students with special educational needs in mainstream schools. International Journal of Inclusive Education, 12 (2), 201-219.

Brattou, F. (2016). Dominoes of reactions for refugees in schools. Retrieved from http://www.kathimerini. gr/877391/article/epikairothta/ellada/ntomino-antidrasewn-gia-ta-prosfygopoyla-sta-sxoleia.

Cassimos, D. C., Polychronopoulou, S. A., Tripsianis, G. I., \& Syriopoulou-Delli, C. K. (2015). Views and attitudes of teachers on the educational integration of students with autism spectrum disorders. Developmental Neurorehabilitation, 18 (4), 241-251.

Charavitsidis, P. (2009). Teaching the Greek language to migrant parents while teaching mother tongue to their children as factors for improving the overall effectiveness of the school. [Doctoral thesis]. Thessaloniki: Aristotle University of Thessaloniki, Pedagogical Department of Primary Education.

Dafermos, V. (2011). Social statistics and research methodology with SPSS. Thessaloniki: Ziti.

Dimakos, I. C., \& Tasiopoulou, K. (2003). Attitudes towards migrants: What do Greek students think about their immigrant classmates? Intercultural Education, 14 (3), 307-316.

Gotovos, A. (2002). Diversity and education, issues of intercultural pedagogy. Athens: Metaichmio.

Halios, H., \& Pantazis, B. (2012). Foreign students with learning difficulties at school, Teachers' attitudes. Proceedings of the $6^{\text {th }}$ Panhellenic Conference of the Hellenic Institute of Applied Pedagogy and Education, 5-7 October 2012 (pp. 1-8). Athens: Hellenic Institute of Applied Pedagogy and Education. Retrieved from http://www.elliepek.gr/documents/6o_synedrio_eisigiseis/17_Chalios_Pantazis.pdf.

Kalyva, E., \& Agaliotis, I. (2009). Can contact affect Greek children's understanding of and attitudes towards peers with physical disabilities? European Journal of Special Needs Education, 24 (2), 213-220.

Kasimati, K. (2006). The integration of Albanian immigrants into Greek society. In Bagavos, C., \& Papadopoulou, D. (Eds.), Immigration and integration of immigrants in the Greek society (pp. 353-412). Athens: Gutenberg.

Labropoulou, B., \& Panteliadou, S. (2000). Special education in Greece - Critical consideration. In A. Kypriotakis (Ed.), Proceedings of the Pan-European special education conference (pp.156-170). Rethymnon: University of Crete.

McLeskey, J., \& Waldron, N. L. (2002). School change and inclusive schools: Lessons learned from practice. Phi Delta Kappan, 84(1), 65-72.

Milesi, C. (2006). Foreign students from Albania to the school community. Athens: Grigoris.

Özdemir, T., \& Eyduran, E. (2005). Comparison of chi-square and likelihood ratio chi-square tests: Power of test. Journal of Applied Sciences Research, 1 (2), 242-244. 
Padeliadou, S., \& Lambropoulou, V. (1997). Attitudes of special and regular education teachers towards integration. European Journal of Special Needs Education, 12 (3), 173-183.

Panteliadou, S., \& Lambropoulou, V. (2000). Adolescents and young people: Attitudes towards students with special needs and their schooling. New Education, 95, 120-133.

Papazoi, T. (2016). European policy on migrant education and the policy of Greece, The views of primary teachers on the education of foreigner's students in the Greek Primary School. [Diploma Thesis]. Thessaloniki: University of Macedonia, Postgraduate Studies Program in European Youth, Education and Culture Policies.

Patsidou, M. (2010). Inclusive education of children with or without special needs: Attitudes of teachers and students to secondary education. [Doctoral Thesis]. Thessaloniki: Aristotle University of Thessaloniki.

Pavlis, D. (2016). Migrant students challenge in Greek education. In I. Papadatos, S. Polychronopoulou \& A. Bastea (Eds.), Proceedings of the $6^{\text {th }}$ Panhellenic conference of education sciences (Volume II, pp. 10791096), Athens: National and Kapodistrian University of Athens.

Soulis, S. P. (2008). A school for all, from research into practice. Volume B. Athens: Gutenberg.

Tsiakalos, G. (2000). Guide to antiracist education. Athens: Ellinika Grammata.

Tsokalidou, P. (2012). Space for two, bilingualism and education. Thessaloniki: Zygos.

Vaporidi, I., Kokaridas, D., \& Krommydas, C. (2005). Physical education teachers' views on embedding students with disabilities in typical classes. Searches in Physical Education and Sports, 3 (1), $40-47$.

Vassileiou, E., \& Charitaki, G. (2016). Investigation of the views of the teachers of the general order on the integration of students with special educational needs. Pan-Hellenic Congress of Education Sciences, 1, 236-248.

Zoniou-Sideri, A. \& Vlachou, A. (2006). Greek teachers' belief systems about disability and inclusive education. International Journal of Inclusive Education, 10 (4/5), 379-394.

Zoniou-Sideri, A. (2011). The disabled and their education: A psycho-pedagogical approach to integration. Athens: Pedio. 